\title{
PÁLFY ESZTER
}

\section{Gyöngyösi István és Tétsi N. Zakariás - a Murányi Vénus 1702-es kiadásáról}

Gyöngyösi István költészetének megítélésében az eltelt századok során jelentős változások történtek. Mủveinek kortárs, majd 18. századi töretlen népszerüsége után a 19. századi recepciót Kazinczy Ferenc elmarasztaló ítélete határozta meg. Az időközben más szempontokat előtérbe helyező irodalmi ízlés miatt a Gyöngyösi-életmü jelentősége csökkent. Gyöngyösi irodalomtörténeti megítélésében csak az 1980-as években jött el az a fordulat, amely a szövegek korhoz kötöttségét hangsúlyozta: Kibédi Varga Áron nagyhatású Gyöngyösi-tanulmányában ${ }^{1}$ válik először központi jelentőségü gondolattá, hogy a költőt nem a későbbi korok irodalmi elvárásai, hanem saját korának retorikai-poétikai elvei alapján érdemes mérlegre tennünk. A Gyöngyösi-kutatás többé-kevésbé azóta is ezt az elvet követi, újabb és újabb adalékokkal egészítve ki a Gyöngyösi retorikai-poétikai ismereteiröl tudottakat. ${ }^{2}$

Pontosabb képet kaphatunk a Gyöngyösi-költészetről, ha a szövegeket nemcsak retorikai-poétikai kontextusukba helyezzük vissza, hanem az egyes müvek kiadástörténetét is nyomon követjük. A fent ismertetett recepciótörténet tudatosan elnagyolt: jelen dolgozat nem a müvekről alkotott esztétikai és ízlésítéletek kánonképző szerepére koncentrál, hanem a szöveghagyományozódást középpontba állítva tekint a recepcióra.

E szempont mentén a Márssal társolkodó Murányi Vénus 1702-es, kolozsvári kiadását vizsgáljuk. A szövegváltozat kapcsán felmerülő kérdésekhez először a recepciótörténet felől közelítünk, majd (ezzel összefüggésben) a kiadványt korabeli környezetében helyezzük el.

${ }^{1}$ KibÉDI VARGa Áron, Retorika, poétika, müfajok, Gyöngyösi István költői világa = Irodalomtörténet, 1983, 545-591.

2 A KIBÉDI VARGA-tanulmány fordulópontjellegére Jankovics József nyomán utalok. Legfrissebben az ö munkáiból követhető nyomon a Gyöngyösi-recepciótörténet: részletes összefoglalót találhatunk például $A$ szerelem költơi című tanulmánykötetben. A kötet többi Gyöngyösi-tanulmánya a költő retorikai-poétikai ismereteihez szolgáltat adalékot. A szerelem költői, Konferencia Balassi Bálint születésének ötödfélszázadik, Gyöngyösi István halálának háromszázadik évfordulóján, Sárospatak, 2004. május 26-29., szerk. Szentmártoni Szabó Géza, Bp., Universitas, 2007. http://www.iti.mta.hu/Spatak-2004/A_szerelem_koltoi.pdf(2015. december 15.) 


\section{A Márssal társolkodó Murányi Vénus és a 18. századi kiadáspolitika}

A Márssal társolkodó Murányi Vénus Kassán jelent meg elöször nyomtatásban 1664-ben. Fennmaradt kézirat híján a szakirodalom ezt tekinti a hiteles Gyöngyösiszövegnek. Ezt a mü 1702-es kolozsvári kiadása követte, amely nagymértékben eltért az 1664-es szövegtől, s amely döntő jelentőségűvé vált a Gyöngyösi-recepció történetében. Címlapján a következő́t olvashatjuk: „mostan pedig újjabb meg-jobbitásával a' verseknek ki-botsáttatott.” A „megjobbítás” jelentős változtatásokat jelent: számos strófa kimaradt (föként mitológiai analógiák, részletező leírások), más, az eredetiben nem szereplő strófák viszont helyet kaptak a szövegben. A mindkét változatban egyaránt megtalálható versszakok is alakultak: az 1702-es kiadás jó néhány retorikai alakzattal egyszerübb, és sajtó alá rendezője szemmel láthatóan nincs birtokában a Gyöngyösi által követett költői hagyománynak. ${ }^{3}$

A 18. és 19. század Murányi Vénus-kiadásai mind ezt a szöveget veszik alapul, s nem nyúltak vissza az 1664-es első változathoz. Nemcsak a 18. századi utánnyomások, ${ }^{4}$ hanem az olyan kanonikus értékkel bíró rendezett kiadások is, mint Dugonics Andrásé 1796-ból vagy Toldy Ferencé 1864-ből az 1702-es szövegváltozatból kiindulva készültek el.

Demeter Zsuzsa kötete a 18. század végének Gyöngyösi-képét állítja középpontba. ${ }^{5}$ Azt vizsgálja, milyen kiadáspolitikai elvek állhatnak a különböző korokban keletkezett Gyöngyösi-kiadások mögött, s ezek miként jelzik a kánon változásait. ${ }^{6} \mathrm{~A} 18$. századi megjelenéseket tanulmányozva kétféle kiadáspolitikát különít el: egyrészt a korabeli nyomdászok olvasói népszerüségre alapozó gyakorlatát, másrészt a század végének már a felvilágosodás irodalomszemlélete jegyében szerveződő kiadási törekvéseit. Az előbbi típusú kiadáspolitika Demeter jellemzésében nagy mennyiségű romlott szövegü kiadáshoz vezet, amelyeknél nem jelenik meg célként a szerzőség tisztázása vagy a szövegek rekonstrukciója. Meglátása szerint ezzel ellentétben a századvégi kiadási törekvésekben viszont fontos szemponttá válik a szerzői életmü kijelölése, valamint az eredeti kiadások alapján történő szövegközlés. ${ }^{7}$

Demeter általánosságban megfogalmazott kiadáspolitikai elkülönítését a $M u$ rányi Vénus 18. századi továbbélésén vizsgálva megállapítható, hogy e mủ esetében is a 18. század végén merül fel először az első, eredeti változathoz való

${ }^{3}$ Készülő doktori disszertációm egyik fejezetében részletesen összehasonlítom a két szövegváltozatot.

${ }^{4}$ A Nyerges Judit által összeállított Gyöngyösi-bibliográfia tíz Murányi Vénus-kiadást tart számon a 18. századból. A bibliográfia elérhető itt: http://mek.niif.hu/03800/03890/03890.htm (2015. december 15.).

5 Demeter Zsuzsa, Költői tradició és könyvkiadás, Gyöngyösi István példája, Kolozsvár, Erdélyi Múzeum-Egyesület, 2014 (Erdélyi Tudományos Füzetek, 282).

${ }^{6}$ Uo., 23.

7 Uo., 23. 
visszatérés igénye, a választóvonal pedig valóban érzékelhető a 18 . század során készült nagyszámú kiadás és a 18. század legvégén, 1796-ban kiadott Dugonics András-féle változat között.

A 18. század végi irodalomtudósok találkoztak tehát elsőként a szövegkiadás problémáival a Murányi Vénus kapcsán is - legfőképp azzal, hogy az 1702-es szövegváltozat lényegesen eltért az 1664-estöl. Megjelent a kétkedés az 1702-es kiadás „meg-jobbításával” kapcsolatban, s ettől kezdve bélyegzik rontottnak a kiadást. A negatív ítéletet kiváltó eltérés kétségtelen, fontos látnunk azonban a különbséget a 17-18. század fordulójának és a 18. század végének kiadási módszerei, elvei között.

A 17-18. század fordulóján születő kiadások jellemző gyakorlata, hogy a kiadó - a szerzőt még nem kitüntetett helyen kezelve - szabadon belenyúlhat egy-egy kéziratba, módosíthat a szövegen. Gyöngyösi maga is buzdít hasonlóra a Porábúl megéledett Főnix utószavában: „Mindazonáltal, akik azokhoz többet értenek nálomnál, azok censurája alá örömest bocsátom azokat, és amit correctióra valót találnak azokban, aminthogy találnak is, annak megigazításátúl nem fogom meg kezeket, sőt kedvesen veszem azt tőlök // mind a magam, mind azok részérül, akik a magyar versek olvasásában gyönyörködvén, ezt az én munkácskámat nem restellik szemek eleiben venni, akik legyenek ezekkel jó egészségben és éljenek sokáig." "Noha az ilyen jellegü szerzői szerénykedés kötelező toposznak tartható, topikus voltával együtt is rávilágít a szövegek korabeli kezelésének jellegére.

Hasonlóan vélekedik Gyöngyösi szövegeiről Gyenis Vilmos is. Kiemeli, hogy Gyöngyösi korában a szövegek változtatására és alakítására még jóval több a lehetőség. Véleményét a kéziratosság dominanciájára és a korabeli olvasói elvárásokra alapozza. ${ }^{9}$

Ettől a gyakorlattól a 18. század végének kiadáspolitikája jelentősen eltér. Ekkor már ténylegesen beszélhetünk szúkebb értelemben vett kiadáspolitikáról, előzetes koncepcióról, célokról. A 18. század végén „Gyöngyösi müveinek kiadása [...] már alárendelődik a szerzői életmünek - célja nemcsak a szerzői biográfia megalkotása, hanem a minél alaposabb és minél teljesebb életmükiadás". ${ }^{10}$

${ }^{8}$ GYÖNGYÖSI István, Porábúl megéledett Fönix avagy Kemény János emlékezete, szöveggond. és jegyz. Jankovics József, Nyerges Judit, utószó Jankovics József, Bp., Balassi Kiadó (Régi Magyar Könyvtár, Források 10), 200.

${ }^{9}$ GYENIS Vilmos, Gyöngyösi: a korigények és a közizlés = Irodalomtörténet, 1980, 105-134, 113 114. http://epa.oszk.hu/02500/02518/00221/pdf/EPA02518_irodalomtortenet_1980_01_105-134.pdf (2015. december 15.) - „Életében művei túlnyomórészt csak kéziratos formában terjedtek. A kéziratból olvasók és a másolatok olvasói más igénnyel fordultak a műhöz, mint a nyomtatott irodalom részesei, s Gyöngyösinek magának is számítani kellett erre. [...] Emitt még a változtatásnak és alakításnak nagyobb lehetőségei voltak adottak, s mint maga is tapasztalhatta, a kortársak éltek is e lehetőségekkel."

${ }^{10}$ Demeter 2014, i. m. 24. 
Egy Gyöngyösi-kiadás tervei a 18. század végén

Ráday Gedeon 1787-ben egy kritikai kiadást tervezett Gyöngyösi műveiből, a nyomdával való egyeztetést Szerencsi Nagy Istvánra bízta. Szerencsi kéri is Rádayt, hogy küldje el ,a jó originalis editiókat és az ezek eleibe tejendő praefatiót." "11 Ráday vállalkozásával párhuzamosan Kovásznai Sándor marosvásárhelyi professzor is dolgozott egy Gyöngyösi-kiadáson, azonban sem Ráday, sem Kovásznai nem tudta véghezvinni a tervet, 1792-ben mindketten meghaltak.

Ráday halála után Füskúti Landerer Mihály könyvkiadó Dugonics Andrást kérte fel. Dugonics előszavában rögzíti, hogy munkájában hibajavító és tisztázó szándék vezérli: meg szeretné tisztítani a Gyöngyösi-szöveget mindazoktól a hibáktól, amelyek a 18. századi kiadásokkal kerültek bele. Hiába azonban a nemes szándék, Dugonicsnak nem sikerült megszereznie a Murányi Vénus első kiadását. Jobb híján az 1767-es és 1775-ös kiadásokból dolgozott, s megjegyzi a Murányi Vénus 1775-ös kiadásáról, hogy ,noha ugyan temérdek hibákkal tele van, de mindazokat ki-pótollya VESELÉNYI Ferencznek azon képe, melly a könyv eleibe függesztetett”. Dugonics - mint látjuk - szeretné kárpótolni olvasóit, az eredeti Gyöngyösiszöveg helyett egy Wesselényi-portré azonban sovány vigasz marad.

A 18. század végi törekvésekben mindenesetre észrevehető, hogy Gyöngyösi mint szerző felértékelődött. A korábbi, 18. századi kiadásokkal ellentétben itt nem az önmagában vett és népszerü történet, hanem a szerzői névhez rendelhető szöveg válik központi szerepüvé. Az „originalis editió” megszerzése csak egy szerzőközpontú irodalom-felfogás jegyében tüzhető ki célul.

\section{Az 1702-es kiadás megitélése}

A 18. század végén induló Gyöngyösi-recepció hangsúlyos eleme a véleményformálás az 1702-es kiadásról. Ekkor fogalmazódott meg az a vélemény a kiadásról, amely többé-kevésbé azóta is tartja magát. Verseghy Ferenc 1793-ban a következőket írta: „A kolosvári herélő, a ki Murányi Vénust 1702. esztendőben kiadta, s a kit azután a többi nyomtatók is követtek, - halhatatlan Gyöngyösinek szép gondolattyát fogytig megrontotta”. Majd így folytatja: „Valahány szó, melly a kolozsvári kiadónak agyvelejéből származik, annyi szentségtörés, annyi méreg-forrasztó kábaság." 12

${ }^{11}$ Szerencsi Nagy István levele Báró Ráday Gedeonhoz, közread. Kis Áron = Figyelö, Bp. $1876,1,182-184$.

12 Verseghy Ferenc, Mi a poézis? és ki az igaz Poéta? Buda, 1793. https://books.google. hu/books?id=srJeAAAAcAAJ\&pg=RA1-PR9\&lpg=RA1-PR9\&dq=verseghy+ferenc + mi + a +po $\% \mathrm{C} 3 \% \mathrm{~A} 9 \mathrm{zis}+\% \mathrm{C} 3 \% \mathrm{~A} 9 \mathrm{~s}+\mathrm{ki}+\mathrm{az}+\mathrm{igazi}+$ po $\% \mathrm{C} 3 \% \mathrm{~A} 9$ ta? $\&$ source $=$ bl\&ots $=3 \mathrm{Exwc} 88 \mathrm{Mv}-$ F\&sig=uoL8mnMPVc6pMputK51pGAqBQCU\&hl=hu\&sa=X\&ei=ILMaVe-3H8T_UrX1g8gD\&ved $=0 \mathrm{CC} 8 \mathrm{Q} 6 \mathrm{AEwAw} \# \mathrm{v}=$ onepage $\& \mathrm{q}=$ verseghy $\% 20$ ferenc $\% 20 \mathrm{mi} \% 20 \mathrm{a} \% 20 \mathrm{po} \% \mathrm{C} 3 \% \mathrm{~A} 9 \mathrm{zis} \% 20$ \%C3\%A9s\%20ki\%20az\%20igazi\%20po\%C3\%A9ta\%3F\&f=false (2015. december 15.) 
Célszerü körüljárni, milyen irodalom-felfogás húzódik meg a fenti gondolatok mögött. Verseghy a kiadás kapcsán konkrét személyt hibáztat: sérelmezi, hogy egy dilettáns elrontotta az alapvetően szép gondolatú és halhatatlan Gyöngyösit. Szembetűnő, hogy ez a megközelítés nem tartja szem elött a kiadás keletkezésének, a 17-18. század fordulójának szövegkiadói gyakorlatát: Verseghy nem a régiség eltérő kiadási módszerének példájaként értékeli a szöveget, hanem saját korából indul ki. Ez a kor a szerző személyét egyre kiemeltebb helyen kezeli - Verseghy tehát ebből a nézőpontból ítéli meg az 1702-es kiadást is.

Az irodalmi gondolkodásban bekövetkező változások, vagyis a szerző megnövekedett szerepe közrejátszik abban, hogy Gyöngyösi elkezd kultikus figurává válni. E rajongó magatartásra számtalan példa idézhető a 18. század végéről. Verseghy a „halhatatlan Gyöngyösi”-ről beszél, Kovásznai Gyöngyösi „drága gyöngy verseit”, valamint „drágalátos és bölcs munkái”-t emlegeti. Gvadányi József véleménye szerint „nála nagyobb poétát magyar anya még nem szült.”13 Gyöngyösi személyét tehát magas polcra helyezte az irodalmi közbeszéd, ebből a pozícióból pedig nem nehéz az 1702-es kiadást Gyöngyösi elleni támadásnak vélni - s kárhoztatni a támadót.

A 19. században Gyöngyösi kissé kikerült az irodalmi vizsgálódás homlokteréből: ahogyan Demeter Zsuzsa írja, a 18. század legnépszerübb költőjének hanyatlása az első rendszerezett kiadással kezdődött. ${ }^{14} \mathrm{~A} 19$. század tulajdonképpen megelégszik a Dugonics-féle kiadás örökségével, az egyetlen említésre méltó közlés Toldy Ferencé, aki szintén a Dugonics-féle változatot veszi alapul, s nem kutatja fel az 1664-es szöveget.

A 20. század elején Badics Ferenc nevéhez köthető a Gyöngyösi-recepció nagy fordulata, aki az eredeti szöveg kritikai kiadását készítette el. Badics Verseghyhez hasonlóan gondolkozott: megsemmisítő véleménnyel van az „1702-i hamisított kolozsvári kiadás”-ról, vagyis ,a romlott, és nem az egyedül hiteles eredeti szöveg”15-röl. Többször is hangsúlyozza: „ez, a kétszáz éven át (1702-1904) utána nyomtatott többi kiadással együtt, mind hamisítvány". ${ }^{16}$ Badics, noha tulajdonképpen tisztában van a korábbi korszak eltérö szövegkiadási gyakorlatával, mégis mintha Verseghyhez hasonlóan járna el, s későbbi korok irodalmi elveit kérné számon a kiadáson: „Akkoriban a kritikai érzék oly kevés, a kiadás és az önkényes átdolgozás tekintetében pedig a szabadság még jóval később is oly nagy volt, hogy mindenki büntetlenül tehette rá kezét a mások szellemi termékeire."17 - írja a kritikai kiadás kísérőtanulmányában.

Badics érdeme vitathatatlan a Gyöngyösi-filológiában: a 20. század második felének recepciója nagyrészt az ő Gyöngyösi-tanulmányait tartja kiindulási alap-

13 Idézi BADICs Murányi Vénus-kiadásának kísérőtanulmányában: GYöNGYöSI István, Márssal társolkodó Murányi Venus, kiad. és bev. BADICs Ferenc, Bp., 1909, XXXVIII.

14 Demeter 2014, i. m. 22.

15 BADICS 1909, i. m. LIV.

16 Uo., LI.

17 Uo., XXXV. 
nak. Ez viszont azt is jelenti, hogy az 1702-es kiadás tekintetében a szakirodalom legújabban is Badics retorikájára épít, amely szerint a Murányi Vénus méltatlan hamisítás áldozata lett.

A Murányi Vénust legutóbb Jankovics József adta ki 1998-ban. Kísérőtanulmányában Jankovics egyetértőleg idézi Badicsot: a kiadó személyéről mint „sajtó alá hamisító”-ról beszél, a kiadást pedig „filológiai büntett”-nek nevezi, amelynek elkövetőjeként Tsétsi Zachariást nevezi meg. ${ }^{18}$ Badics és Jankovics nyomán Demeter Zsuzsa szintén mint ,a hamisítót” tárgyalja az immár névvel is rendelkező 1702-es kiadót. Látnunk kell azonban, hogy az 1702-es kiadás büntényként és csalásként való értékelése nem a kiadás keletkezési korának elvei szerinti véleményformálás, hanem az irodalmi gondolkodást a 18. század végétől meghatározó szerzőközpontúság felőli ítélet.

\section{T(s)étsi Zakariás a Gyöngyösi-kutatásban}

Jankovics és Demeter tehát Tsétsi Zakariást tartja az 1702-es Murányi Vénuskiadás „megjobbítójá”-nak - a Régi Magyar Nyomtatványok 2012-ben megjelent kötete tőlük átvéve említi „Csécsi Zakariást” mint átdolgozót. ${ }^{19}$ A néven kívül azonban más információt sem Jankovics, sem Demeter nem közöl. Joggal merülhet fel a kérdés, mit tudhatunk Tsétsi (mint látni fogjuk, helyesen Tétsi) Zakariásról?

Az 1702-es kiadás név nélkül jelenik meg, a Murányi Vénus szövegét azonban egy Gyöngyösi érdemeit magasztaló vers előzi meg. A hét strófából álló költemény a következő címet viseli: „Tisztelem Én is Tudományának Szépségét Jelentő s Nagy Zengéssel a' Castalus Hegyéről Alá Repült Irását, Álmélkodván Szépségén Gyöngyösi István Magyar Verseinek.” Amint arra már Kovásznai Sándor felhívta a figyelmet, a cím kezdőbetüiből egy név olvasható ki. Kovásznai egy Rádaynak címzett levélben így ír: „Azt már könnyen el-hiszem és meg-engedem hogy a' Murányi Vénus' eleibe irt hét strófa Tétsi Zachariásé, mellyeknek titulussában a' szóknak első betüiben az a’ Név vagyon belé tsinálva.” Kiegészítésképp pedig egy másik levélhelyen: „, [...] meg-lehet hogy mikor a’ Murányi Venus elöször ki-nyomtattatott, akkor irta Tétsi az eleibe ezen applausust." ${ }^{20}$

Kovásznai itt nem utal arra, hogy maga a kiadás is Tétsi Zakariás nevéhez kötödik, csupán azt jegyzi meg, hogy az említett Gyöngyösit dicsőítő versnek ő a szerzője. Később Badics az 1909-es kritikai kiadás kísérőtanulmányában is hivatkozik erre a Kovásznai-szöveghelyre: „A kezdő-betűkből, mint már Kovásznai S.

${ }^{18}$ GYÖNGYÖsI István, Márssal társolkodó Murányi Vénus, szöveggond. és jegyz. Jankovics József, Nyerges Judit, utószó Jankovics József, Bp., Balassi Kiadó, 1998 (Régi Magyar Könyvtár, Források 8), 192. http://www.balassikiado.hu/BB/netre/html/venus/venus.html (2015. december 15.)

19 Régi Magyarországi Nyomtatványok 1656-1670 (4. kötet), szerk. P. Vásárhelyi Judit, Bp., Akadémiai, 2012, 506. http://mek.oszk.hu/11900/11979/11979.pdf (2015. december 15.)

${ }^{20}$ Kovásznai Sándor leveleit Demeter Zsuzsa közli 2011-es disszertációjának mellékletében, a szöveghelyeket innen idézem. 
(1790) észrevette (Figyelő, 1876, 373, 1.): »Tétsi Zakariás neve tünik ki, ő tehát a vers szerzője (s talán a kiadásé is) «; de verse miatt joggal mondja őt Kovásznai »igen sületlen elméjü ember«-nek."21 Badics 1909-ben tehát csak feltételesen állítja, hogy az említett vers címének kezdőbetüiből kibontakozó Tétsi Zakariás az átdolgozó és kiadó. 1939-es Gyöngyösi-monográfiájában Badics azonban már bizonyossággá teszi a „talán”-t: „Az 1702-iki »csapni való kiadásnak« (Ráday szavai) eszközlője Tétsi Zakariás (mint ez a Gyöngyösit magasztaló verseinek kezdőbetüiből kitünik)"22 - írja. Nézzük, mi változtathatta álláspontját bizonyossággá.

1914-es tanulmányában ${ }^{23}$ Badics azt tüzi ki célul, hogy bizonyítsa: az 1702-es kiadás semmiképp sem eredhet Gyöngyösitől. (Gyöngyösi 1702-ben még él, tehát joggal feltételezhetnénk ennek ellenkezöjét is.) Ha ekkoriban Badics tudta volna bizonyosan, s nem csak „talán”, hogy Tétsi Zakariás műve a kiadás, nyilvánvalóan nem szentel egy egész tanulmányt annak, hogy kifejtse, nem Gyöngyösi áll a szöveg átdolgozása mögött. Badics véleményének változása valószínúleg egy időközben publikált Ráday-szövegnek tudható be: Ráday Gyöngyösi munkáinak Chronologica rendi cím alatt veszi sorra Gyöngyösi müveit, s beszámol mindarról, amit az egyes kiadásokról tud. Ez a Gyöngyösi-kronológia azonban csak 1938-ban jelenik meg. ${ }^{24}$ Badics valószínúleg kéziratban sem ismerte korábban, mert 1909-es és 1914-es tanulmányaiban nem hivatkozik rá. Az 1939-es monográfia azonban már tud a Ráday-féle összegzésről. Ezt írja Ráday a Murányi Vénus kapcsán:

„Muranyi Venus Első Editioja jött ki, Kassan 1664-ben [...] Ezen Editio van dedicalva Palatinus Groff Vesselenyi Ferentznek és Gr Szétsi Anna Marianak, és circiter 400 rendel vagyis 50 Strophával több van benne, mint az Ujabb Editiókba. Ez úgy láttszik hogy első Munkája néki, leggalabb azok kozt az kiket ki nyomtattatott. Ugyan Annak Második jó Editioja jött 1702-ben ki [...] Kolosvart. Még ezen Editio (jött) eletében nyomtattatott ki, és Tétsi Zacharias a Dedalus Autora applaudált néki: Ebbül ki hagyta azokat a verseket, amelyekkel az elsőb Editio bővebb, nemellyet pedig önként változtatott es edgyetlen egy Strophat Szurt bele melly az első Editioba nints." 25

A megfogalmazásból valószínünek tủnik, hogy a „Tétsi Zakariás applaudált néki” rész kettőspontja után a szöveg egyes szám harmadik személyben Tétsire utal,

${ }^{21}$ BADICS 1909, i. m. XXXI.

22 Badics Ferenc, Gyöngyösi István élete és költészete, Bp., 1939 (A Vármegyei Tisztviselök Irodalmi és Művészeti Gyöngyösi István Társaságának kiadványai, 11.), 202.

${ }^{23}$ Gyöngyösi István összes költeményei, kiad. és bev. Badics Ferenc, 1-4, Bp., 1914-1937, (RMKT).

${ }^{24}$ Id. Gróf RÁDAY Gedeon, Gyöngyösi munkáinak Chronologica rendi = Gyöngyösi-almanach, Bp., Gyöngyösi István Társaság, 1938 (A Vármegyei Tisztviselők Irodalmi és Mủvészeti Gyöngyösi István Társaságának kiadványa, 3), 137-140.

${ }_{25}$ Uo., 137. 
s nem magára Gyöngyösire. Ráday fogalmazza meg tehát először azt a véleményt, amely szerint mind a magasztaló vers, mind pedig a kiadás Tétsi Zakariás mủve.

Többet is megtudhatunk Tétsi Zakariásról, ha Ráday és Kovásznai levelezését vizsgáljuk: a 18. század végének két nagy Gyöngyösi-pártfogója még úgy beszél Tétsiről, mintha ténylegesen be tudná azonosítani személyét. Nagy hiány, hogy Ráday levelei nem maradtak fenn - már Badics leírja ezt, s a Gyöngyösi-kutatás azóta sem bukkant nyomukra. Demeter Zsuzsa is csak a Kovásznai által írott leveleket közli disszertációja függelékében. A Ráday-levelek esetében tehát csak tartalom-rekonstruálással lehet próbálkozni - ezt mind Badics, mint Demeter részletesen megteszi. Mi itt csak a Tétsi Zakariást érintő részekre szorítkozunk.

Kovásznai és Ráday levelezésében kiemelt helyet kap a szerzőség kérdése, többek között Tétsi Zakariással összefüggésben is. A Cuma városában épittetett Daedalus temploma címü munka szerzősége vita tárgyát képezi kettejük között. Míg Kovásznai biztos abban, hogy Gyöngyösi müve, Ráday Tétsi Zakariásnak tulajdonítja. A legevidensebb bizonyítékot erre nem is Kovásznai levelei, hanem Ráday saját szavai szolgáltatják az 1938-ban közölt kronológiában: „Nemelylyek, az Ugy neveztetett Dedalus Templomatis az Gyöngyösienek tartyák. De az Tétsi Zachariasse.”26 - írja. Fontos forrásnak bizonyulnak továbbá Zilai Sámuel Rádaynak írott levelei: Ráday Zilaival is tárgyalja a Gyöngyösi-kérdéseket. (A Ráday-levelek valószínúleg itt sem maradtak fenn.) Rádayval ellentétben és Kovásznaival egyetértésben Zilai szintén Gyöngyösit tartja a Daedalus temploma szerzőjének: „Obiter méltóztatott Ngod említeni Levelében, hogy a Daedalus auctora Tétsi Zakhariás volna. Méltóztassék Ngod vélünk közleni honnan vészen ezen értelemre argumentumot: mert mi ezt Gyöngyösinek tulajdonítjuk."27

Noha tehát Kovásznai leveleiből Tétsi Zakariás neve a Daedalus templomának szerzőjeként nem kerül elö, a Ráday-kronológiából és Zilai leveléből tudhatjuk, hogy Ráday neki tulajdonítja. Kovásznai pedig, mint már jeleztük, cáfolja ezt: „Akarnám ha Nagyságoddal egy értelemben lehetnék a 'Daedalus Temploma' irója iránt-is, de én az iránt-is meg-maradok elébbi értelmemben és azt hiszem álhatatoson, hogy azt Gyöngyösi irta."

Elképzelhető, hogy Ráday Kovásznaival folytatott vitájának végén már hajlott Kovásznai álláspontjára, mert Kovásznai így ír utoljára a kérdésről: „Addig hányjuk-vetjük a Dedalus templomát, hogy talán utoljára közelébb jutunk hozzá." Badics ebből arra következtet, hogy Rádayra hatottak Kovásznai érvei. Azt azonban nem tudjuk, sikerült-e a teljes meggyőzés, mert a levelezés megszakadt. ${ }^{28}$

Kovásznai a levelezésben máshol is említi Tétsit. Egy helyen arról számol

${ }^{26}$ Uo., 140.

27 LADÁNYI Sándor, Zrínyi Török áfiuma és Gyöngyösi verseinek XVIII. század végi kiadástörténeti problémáihoz, Zilai Sámuel levelei Ráday Gedeonhoz (1787-1792) = Irodalomtörténeti Közlemények, 1975, 482-498, itt: 493. http://epa.oszk.hu/00000/00001/00294/pdf/itk_EPA00001 1975_04_482-498.pdf

${ }_{28}$ BADICs Ferenc, Gyöngyösi István ismert és ismeretlen költeményei, Budapest, 1912, (Értekezések a Nyelv- és Széptudományok köréből, XXII), 84. 
be Rádaynak, hogy nemcsak a Murányi Vénus-kiadásban szereplö Gyöngyösidicsérő strófákat szerezte ő, hanem más Gyöngyösi-müvekhez is írt verseket, bár azokat latin nyelven: „Vagynak a’ Phoenix elött-is valami Deák versek, mellyeknek kezdeti ez: Virgilius vates Romanae gloria gentis, Hungaricae nostrae gloria Ing. manes cet. Ezeket könnyen elhiszem hogy Tétsi Zachariáséi. Ugy a'mellyek a' Daedalus Templomának végiben találtatnak és igy kezdetnek: Illa relicta Ariadna feris, nunc improbe Theseu cet."

Ráday és Kovásznai tehát még ismerte Tétsi Zakariás nevét. A 19. század során maguk a Gyöngyösi-müvek is háttérbe szorultak, Tétsi alakja pedig végképp érdektelennek tartható. Badics átvette ugyan a nevet Kovásznaitól, referencialitása azonban már aligha lehetett számára. Bizonytalan Tétsi Zakariás kilétét illetően az 1939-es Badics-monográfia szerkesztője is a Daedalus templomáról írva: „Id. Ráday Gedeon Tétsi Zakariásnak (?) tulajdonítja, alább nevezett kritikai jegyzeteiben. (A szerk. megjegyzése)" ${ }^{29}$

Tétsi következő megjelenése Ladányi Sándor 1975-es közléséhez köthető. ${ }^{30}$ Ladányi a Zilai-levelek Tétsi Zakariásáról lábjegyzetben csak ennyit szerepeltet: „Tétsi Zakariás előttünk ismeretlen személy.” Ezt követően pedig Jankovics Józsefnél kerül elő újra, aki Rádaytól, Kovásznaitól és Badicstól ismeri a nevet. Jankovicsnál, s az 1702-es kiadást Jankovics alapján tárgyaló Demeternél azonban nem Tétsi, hanem Tsétsi Zakariásként szerepel a név.

Tétsi Zakariásról az eddigiek alapján tehát annyi tudható, hogy közepes tehetségü magyarul és latinul is verselö költő, aki nagy tisztelője a Gyöngyösi-életmünek - olyannyira, hogy minden bizonnyal ő rendezi sajtó alá a Murányi Vénust 1702-ben Kolozsváron.

\section{Tétsi N. Zakariás a 17-18. század fordulójának Erdélyében}

Tétsi Zakariásról azonban a Gyöngyösi-kutatástól függetlenül is beszélhetünk. Wix Györgyné és P. Vásárhelyi Judit 2007-ben kiadott Régi magyarországi szerzők kötete tárgyal egy bizonyos Tétsi N. Zakariást: tanuló mivoltát kérdőjellel említi, s két, a kolozsvári református kollégiumhoz köthető alkalmi vers szerzőjeként tartja számon 1698-ból és 1702-ből. ${ }^{31}$ A lexikon forrásként egy 1898-as Dézsi Lajos-cikket jelöl meg, ${ }^{32}$ amely a Szabó Károly által összeállított Régi magyar könyvtár második kötetéhez közli adalékul nyolc egyleveles nyomtatvány

${ }^{29}$ BADICS 1912, i. m. 126.

30 LADÁNYi 1975, i. m.

31 WIX Györgyné, Régi magyarországi szerzők I. A kezdetektöl 1700-ig, szerk. P. Vásárhelyi Judit, Bp., OSZK, 2007, 815.

32 Dézsi Lajos, A kolozsvári református belső templom egyleveles hazai nyomtatványai $=$ Magyar Könyvszemle, 1898, 277-281. http://epa.oszk.hu/00000/00021/00102/pdf/277-281.pdf - Dézsi Zoványi Jenő 1895-ös, részletesebb szövegközlésére támaszkodik: ZovÁNYI Jenő, Egyleveles nyomtatványok s irodalomtörténeti adatok a kolozsvári reformátusok belsö templomában = Irodalomtör- 
főbb adatait. Dézsi közlése alapján Tétsi Zakariás két halotti kártánál müködött közre, a kolozsvári református kollégium alumnusaként mindkettőre egy-egy latin nyelvű gyászverset szerzett. A korábbi, az 1698-as kárta Bátai György kolozsvári református lelkész halálára készült, az 1702-es nyomtatvány pedig Tótfalusi Kis Miklóst búcsúztatja.

A következőkben arra vállalkozunk, hogy e két halotti kárta nyomain elindulva minél teljesebb képet vázoljunk fel Tétsi Zakariás személyéről és az 1702-es kolozsvári Murányi Vénus-kiadás körülményeiröl.

\section{Tétsi N. Zakariás, a diák}

Tétsiről bizonyosan tudhatjuk, hogy kolozsvári tartózkodása elött a nagyenyedi Bethlen Kollégium diákja volt. Erről a nagyenyedi kollégiumból fennmaradt diáknévsor tanúskodik. ${ }^{33} \mathrm{Az}$ évek szerint csoportosított névsorokat Jakó Zsigmond és Juhász István a kollégium ún. aláírási jegyzőkönyvei (matricula studiosorum) alapján adja ki. Ezekben a jegyzőkönyvekben nem szerepel az iskola összes diákja: csupán a felsőbb tudományok tagozatára lépett és bentlakó ösztöndíjas (alumnus) diákokat ismerhetjük meg belölük. ${ }^{34}$ Közéjük tartozott Zacharias Técsi is, aki 1694. október 22-én írta alá a kollégium törvényeit. Utólagos kiegészítésként pedig a következőt olvashatjuk a neve mellett: „Exturbatus ivit Claudiopolim.” ${ }^{35}$ Nemcsak az derül tehát ki, hogy a nagyenyedi kollégium diákja volt, de az is, hogy Nagyenyedröl Kolozsvárra távozott - s hogy ezt valószínúleg nem önszántából tette. Arról, hogy a nagyenyedi kollégiumból miért küldik el, sajnos nincs adatunk.

Tétsi Zakariás lassan kirajzolódó életpályája határozottabb kontúrokat vehet, ha a korabeli erdélyi kollégiumok iskolatörténeti kontextusában szemléljük. E közegben ugyanis megtalálhatjuk mindazokat a mintákat, amelyek Tétsi vonatkozásában is érvényesek.

Herepei János hívja fel a figyelmet arra, ${ }^{36}$ hogy a kisebb falvakból származó fiataloknál a 17. századi kollégiumi feljegyzések az otthoni családneveket a falu nevével helyettesítik. Herepei Gidófalva település diákjait vizsgálja, s megálla-

téneti Közlemények, 1895, 82-95. http://epa.oszk.hu/00000/00001/00030/pdf/ITK_1895_1_065108.pdf

${ }^{33}$ A névsorokat közli: JAKó Zsigmond, JuHÁsz István, Nagyenyedi diákok, 1662-1848, Bukarest, Kriterion, 1979, 91-259.

${ }^{34}$ JAKÓ Zsigmond, A Bethlen Kollégium diáktársadalma a feudalizmus korában = JAKó Zsigmond, JuHÁsz István, Nagyenyedi diákok, 1662-1848, Bukarest, Kriterion, 41-80, 43.

35 JAKÓ, JuHÁsz 1979, i. m. 116.

${ }^{36}$ HerepeI János, Gidófalva deákos végzettségü fiai a XVII. században = Adattár XVII. századi szellemi mozgalmaink történetéhez III, Müvelödési törekvések a század második felében, Herepei János cikkei, szerk. Keserü Bálint, Budapest, Szeged, 1971, 275-281. http://epa.oszk.hu/00000/ 00021/00231/pdf/MKSZ_EPA00021_1958_74_01_056-062.pdf 
pítja, hogy a gidófalvi gyökerü diákok a kollégiumban elvesztik családneveiket (pl. Nagy, Jancsó), s egységesen Gidófalvi vezetéknevüvé válnak. Juhász István tanulmányában Herepei írásából kiindulva úgy véli, hogy ez a nagyenyedi kollégiumra is jellemző gyakorlat lehetett, s feltételezi, hogy a névsor 17. századi diákjainál a származás helyéből formálódott a vezetéknév, elfedve egyúttal az eredeti, otthoni családnevet. ${ }^{37}$ Ez alapján tehát valószínünek kell tartanunk, hogy a nagyenyedi matrikulában szereplő „Técsi Zacharias” Técsőről származott. Annál is inkább, hiszen neve a későbbiekben több helyen Tétsi N. Zakariásként bukkan fel - az N. betü utalhat otthoni, técsői családnevére.

Bélay Vilmos ${ }^{38}$ részletes képet nyújt a korabeli técsői családnevekröl. Az N betüvel kezdődő neveket kiválogatva Técsőről az alábbiak jöhetnek szóba: Nagy, Nehéz, Nikos (Nyikos), Német(hi) ${ }^{39}$ Hogy ezek közül vajon melyiket rövidítheti az $\mathrm{N}$ betü Zakariás esetében, nem tudjuk, sejtésünk szerint azonban árulkodó lehet a Murányi Vénus-kiadásban szereplő Gyöngyösi-dicsőítő vers, amelynek címében (Tisztelem Én Is Tudományának... stb.) a Tétsi N. Zakariás nevet magába foglaló akrosztichon $\mathrm{N}$ betüjét a Nagy szó adja - s miért ne feltételezhetnénk, hogy Tétsi legalább ily módon, az akrosztichonban megragadta a lehetőséget családneve jelzésére?

Azt, hogy Tétsi a kolozsvári református kollégium diákja is volt, a két már említett halotti kárta „coll. alum.” jelzéseiből tudhatjuk, a Herepei János által közölt diáknévsorban nem szerepel a neve. ${ }^{40}$ A névsor alapvetően a subscribált

37 JuHÁsz István, Diákélet a Bethlen Kollégiumban = JAKÓ, JuHÁsz 1979, i. m. 5-40, itt: 23.

38 BéLAY Vilmos, Máramaros megye társadalma és nemzetiségei, A megye betelepülésétöl a XVIII. század elejéig, Bp., Sylvester nyomda Rt., 1943. http://adatbank.transindex.ro/html/ alcim_pdf3409.pdf - Técsőre vonatkozó részek (az online elérhető kiadásban): 205-7.

${ }^{39}$ Herepei János hasonlóképp vizsgálódik Técsi E. András egykori kolozsvári diák körül. L. HEREPEI János, A bánffihunyadi iskola régi nagy mesterei (részlet) = Adattár ...III. 1971, i. m. 353.: „Técsi E. András (1717 körül). A nevét adó Técső máramarosi város lakói között „E” kezdőbetüs családnévül a XVII. század második s a XVIII. század első felében csakis az Erdő nevet találtam. Ez azután a törzsökös lakossághoz tartozott: már az 1600. évi összeírásban a polgárság között megjelenik Stephanus Erdeo, 1614-ben Gasparus Erdő, 1693-ban mint szolgáló s adófizető munkás ember Erdő János, mint marhátlan, gyalogszerrel szolgáló Erdő István, a sóvágók között másik Erdő István, 1715-ben Erdő Gáspár és 1720-ban két Stephanus Erdő. Tekintettel arra a körülményre, hogy e családnév eredetileg személynévből származott (így például Uglya birtokosa 1389-ben Erdő fia Aprusa), mutatja e polgárcsaládnak abból az időből való származását, amikor e név még mint egyéni (személyi) név volt közhasználatos. Tehát e Técsi András is az Erdő-család tagjai közé tartozott, apja pedig, vagy János, vagy valamelyik István szegénysorsú munkásember lehetett. Técsi az 1707 körüli időben lépett Kolozsvárt a diákok sorába, s mint kollégiumi tanuló az 1709. szeptember 28-án elnyugodott Szathmár-Némethi Mihály professzor emlékére nyomtatásban is megjelent nyolcsoros latin verset szerzett."

${ }^{40}$ Herepei egyrészt a Török István által közreadott névsorra (az 1905/06-os tanév értesítőjének függelékében, TÖRÖK István, A kolozsvári collegium tanulóinak névsora = A Kolozsvári Ev. Rev. collegium Értesitője az 1905/6. tanévröl, Kolozsvár, 1906), másrészt pedig saját levéltári kutatásaira támaszkodik. Az általa összeállított, 1668-tól kezdődő és 1817-ben lezárt névsor első felét az 1971-es Adattár-kötetben olvashatjuk (HerePeI János, A Kolozsvári Református Kollégium 
alumnus diákok neveire épül, ők azok, akik aláírták az iskola törvényeit, s akik épp ezért a legkönnyebben tarthatók számon az utókor számára. Herepei azonban nem állítja, hogy az általa gyüjtött nevek teljes mértékben lefedik az egykori kolozsvári diákságot: az aláíró, bentlakó alumnusok és a néhány más forrásból összeszedett publicus diákok nevei mellett említ olyanokat is, akik más, nem iskolai forrású alumniumból éltek, s akiknek a nevei az iskolai névsorokban nem találhatóak meg. Herepei leírja, hogy az általa közölt névsor nem teljes, s olyan kutatókat buzdít a kiegészítésre, akik hozzáférnek például az Apáczai-albumban a patrónusok és pártfogoltjaik jegyzékéhez. „Lényeges ugyanis azt is tudnunk, hogy különösen Bánfi Dénes és Teleki Mihály utódaira átszálló kötelezettségét élvező kolozsvári, enyedi, vásárhelyi, udvarhelyi alumniuma kiknek tette lehetővé a tanulást, minthogy a Habsburg-uralommal beköszöntött súlyos idők nagyon sok más tanulmányi segély alapjait tették tönkre.” ${ }^{41}$ - írja Herepei. Mivel az ismert két halotti kárta tanúsága szerint Tétsi alumnus volt, feltételezhetjük, hogy alumniumát máshonnan, nem az iskolától kapta. Feltételezésünket ebben az esetben is megerősítheti, ha más erdélyi kollégiumi diákokról végzett kutatásokkal vetjük egybe Tétsi helyzetét. Ezúttal Herepeinek a dési református iskola 17-18. századbeli tanárainak névsorait közlő munkája lehet segítségünkre. Egy Márkusfalvi Miklós nevü diákról például (aki a dési kollégiumi jegyzékben már tanárként találunk meg) Herepei leírja, hogy Kolozsváron tanult, és hogy Teleki Mihály kővári főkapitánytól kapott alumniumot, a kollégiumi tanulók névsorában azonban nem szerepel - csak az Apáczai-albumban bukkanhatunk rá nevére. ${ }^{42} \mathrm{Az}$ Apáczai-albumból azonban, mint a fenti idézetből kiderül, Herepei nem tárt fel minden nevet. Valószínüsíthetjük tehát, hogy Tétsi Zakariás Márkusfalvihoz hasonlóan külső alumniumból élő diák lehetett, s nevét ezért nem találjuk a kolozsvári diákok névsorában.

\section{Az 1702-es Murányi Vénus-kiadás}

A Murányi Vénus 1702-ben (RMK I. 1652) név nélkül jelent meg, impresszumában ezt olvashatjuk: KOLOSVARATT - Nyomtattatott MDCCII Esztendőben.

Apáczai utáni diákjainak névsorából (részlet) = Adattár...III. 1971, i. m. 334-349. http://epa.oszk. hu/00000/00021/00231/pdf/MKSZ_EPA00021_1958_74_01_056-062.pdf), második felét pedig Sas Péter rendezte sajtó alá 2004-ben, Herepei több, addig kiadatlan tanulmányával együtt. (HEREPEI János, A Kolozsvári Református Kollégium Apáczai utáni diákjainak névsorából (Második rész) = Uö., A kolozsvári Farkas utcai református templom és kollégium történetéböl, sajtó alá rend., szerk. és az előszót írta Sas Péter, Kolozsvár, Mủvelődés, 2004)

${ }^{41}$ Hereper, A Kolozsvári Református Kollégium Apáczai utáni ... = Adattár...III. 1971, i. m. 335.

${ }^{42}$ Herepei János, A dési református iskola XVII. és XVIII. századbeli igazgatói és tanitói, Minerva irodalmi és nyomdai müintézet, R.-T. Kolozsvár, 1941 (Erdélyi Tudományos Füzetek, 130) 7. http://mek.oszk.hu/07500/07597/07597.pdf 
Kolozsváron 1702-ben két nyomda is müködött: a református egyházközség és a református kollégium Tótfalusi Kis Miklós által vezetett nyomdája, valamint az unitáriusok nyomdája, Kmita (Lengyel) Andrásné vezetésével. A $M u$ rányi Vénus kiadásának éve azonban nem zürzavaroktól mentes időszak a kolozsvári nyomdászat történetében. Tótfalusi Kis Miklós 1702. március 20-án halt meg, nyomdafelszerelésének azonban csak egy része van a református egyházközség tulajdonában, másik része Tótfalusi saját készlete. ${ }^{43} \mathrm{Az}$ előbbi nyomdai eszközöket 1702 . május 20 -ai dátummal kezdődően kapja bérbe az egyházközségtől Tótfalusi egykori nyomdászlegénye, Telegdi Pap Sámuel, ${ }^{44} \mathrm{az}$ utóbbiakat viszont még évek múlva is a hagyatékban, Tótfalusi özvegyénél találjuk. ${ }^{45}$

Ferenczi Zoltán ${ }^{46}$ a Murányi Vénust Telegdi Pap 1702-ből származó nyomtatványai között tartja számon, besorolását azonban nem indokolja, s egyéb adatot sem közöl a kiadásról. A szakirodalomban ezt követően nem találunk kísérletet a nyomtatvány nyomdához vagy névhez kötésére.

A történet a most már jobban megismert Tétsi Zakariást középpontba állítva válik különösen érdekessé. Láttuk, hogy Tétsi mind Nagyenyeden, mint Kolozsváron a református kollégium diákja, s református kötődésủek a halotti kárták is, amelyekre gyászverset szerez: Bátai György református lelkész, Tótfalusi pedig a református egyházközség nyomdáját vezeti. Joggal gondolhatnánk tehát, hogy a kiadvány, amelyet Tétsi nevéhez kötünk, református nyomdából kerül ki; a Tótfa-

${ }^{43}$ Haiman György, Tótfalusi Kis Miklós betümetszői és tipográfusi hagyatékához = Uö., A könyv mühelyében, Budapest, Szépirodalmi Könyvkiadó, 1979, 19-38, itt: 24.

${ }^{44}$ A bérbeadásról az okiratot Jakó Zsigmond közli: Erdélyi Féniks, Misztótfalusi Kis Miklós öröksége, Bevezető tanulmányokkal és magyarázó jegyzetekkel közzéteszi JAKó Zsigmond, Bukarest, Kriterion, 1974, 373-374.

45 Azok a levelek, amelyekben az özvegy még 1711-12-ben is kéri az egyházközséget, hogy vásárolják meg tőle a hagyatékban maradt nyomdai eszközöket, szintén Jakó Zsigmond közlésében olvashatók: Erdélyi Féniks, i. m. 374-375, 384-385.

${ }^{46}$ Ferenczi Zoltán, A kolozsvári nyomdászat története, Kolozsvár, Kereskedelmi és Iparkamara, 1896. http://mek.oszk.hu/07800/07852/07852.htm (2015. december 07.) 
lusi halála utáni időszakban igen könnyen elképzelhető lenne egy afféle árván maradt nyomda nem hivatalos termékeként.

Mindenekelőtt azonban érdemes megvizsgálni a kiadványt nyomdászati szempontból. Név nélkül megjelent kiadással van dolgunk, így a nyomda beazonosításában a betütípusok, iniciálék, fejléc- és záródíszek lehetnek segítségünkre. A vizsgálatnál az egyes nyomtatványok összevetésén túl a Bánfi Szilvia, Pavercsik Ilona, Perger Péter, V. Ecsedy Judit által összeállított kiadvány nyújtott végső bizonyítékot ${ }^{47} \mathrm{E}$ kötet segítségével a nyomdahely pontosan megállapítható: az illusztrációk összevetése alapján az 1702-es Murányi Vénus egyértelmüen a Kolozsváron 1697 és 1703 között müködő unitárius nyomda kiadványa. Az általunk tárgyalt nyomtatvány betüi, díszei és iniciáléi kivétel nélkül megtalálhatóak a kolozsvári unitárius nyomdáról közölt illusztrációk között.

Az unitárius nyomda fejléc- és záródíszei:48

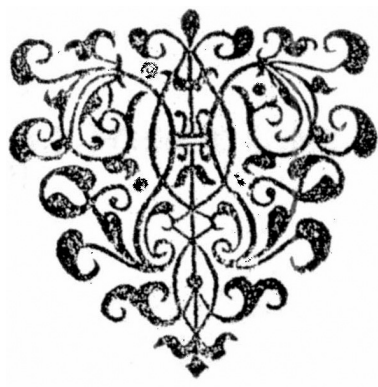

W/L

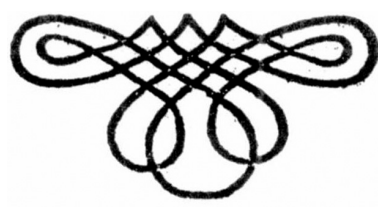

$\mathrm{TV} / 2$

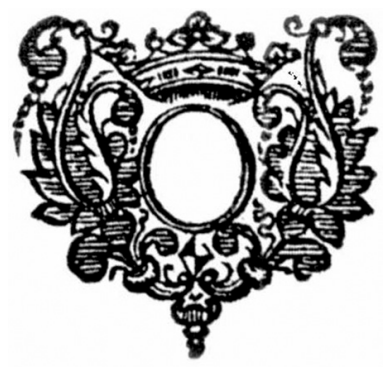

$\mathbb{N} / 4$

A díszek az 1702-es Murányi Vénusban:
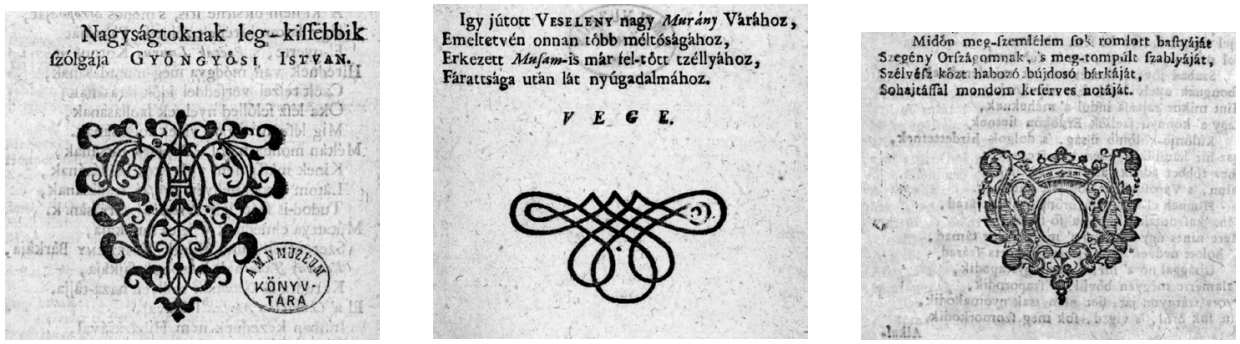

${ }^{47}$ BÁnfi Szilvia, Pavercsik Ilona, Perger Péter, V. Ecsedy Judit, A régi magyarországi nyomdák betüi és díszei XVII. század, Illusztrációk, Balassi Kiadó, Országos Széchényi Könyvtár, Budapest, 2014.

48 Uo., 1021. 
Az unitárius nyomdából származó iniciálé az Illusztrációk-kötetből: ${ }^{49}$

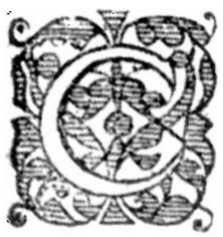

Iniciálé a Murányi Vénusból:

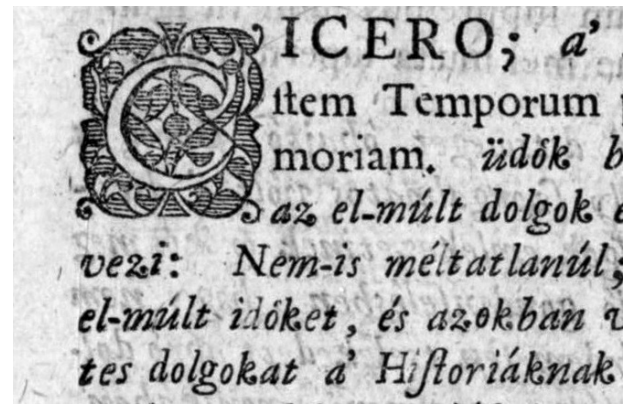

Fejléc egy szintén 1702-es unitárius nyomtatványból (Lucius Annaeus Florusnak, A'Romai viselt dolgokról irott negy könyve. KOLOSVARATT, LENYGEL ANDRASNENAL, Helczdörffer Mihály által. Anno 1702.): ${ }^{50}$

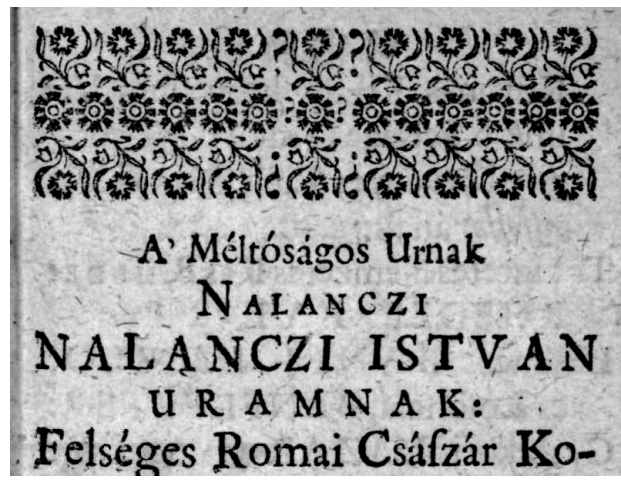

Fejléc a Murányi Vénusból:

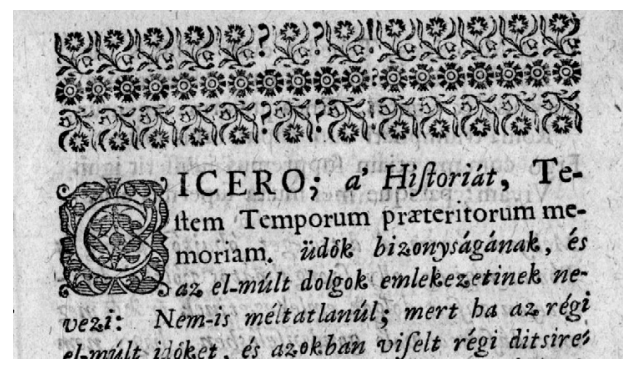

49 Uo., 1022.

50 RMK I. 1649, online elérés: http://rmk.hungaricana.hu/hu/view/RMK_I_1649/?pg=3\& layout $=$ s (A LENYGEL szó a nyomtatvány sajtóhibája - P. E.) 
A nyomdászati összevetés alapján tehát megállapítható, hogy Ferenczi Zoltán tévesen sorolja a Murányi Vénust Telegdi Pap Sámuel kiadványai közé, a kiadás egyértelmüen a Kmita Andrásné által vezetett unitárius nyomda terméke. A Telegdi Pap Sámuel-nyomtatványokkal azonban nem mutat hasonlóságokat az 1702-es Murányi Vénus. Ez a díszek és iniciálék különbözősége mellett az ékezeteknél is megfigyelhető. Ha még a Telegdi Pap-korszak elött vizsgálódunk, a Tótfalusinyomda betüiről Haiman György írja le, hogy Tótfalusi „saját betüin magyar szokás szerinti ékezeteket használ, nem helyettesítve az $\ddot{o}, \ddot{u}$ kettős ékezetét az $o, u$ betü felett elhelyezett kis e betüvel." ${ }^{\prime 51}$ Telegdi Pap kiadványai, mivel Tótfalusi betűivel dolgozik, szintén $\ddot{o}$ és $\ddot{u}$ betüket tartalmaznak, ellentétben az unitárius nyomtatványokkal és a Murányi Vénusszal, amelyek következetesen az $o$ és $u$ betük feletti $e$-vel jelölik a kettős ékezetet.

A Murányi Vénus nyomdájának azonosítása után azonban különböző kérdések merülnek fel: hogyan kerül Tétsi Zakariás unitárius környezetbe? Biztosak lehetünk-e abban, hogy a kiadvány valóban Tétsi Zakariás közremüködésével jött létre? Ha alaposabban megvizsgáljuk az unitárius nyomda történetét, legalábbis valószínüsíthető válaszokat találhatunk. ${ }^{52}$

Kmita Andrásné Lengyelországból érkezik Kolozsvárra, s az ő költségén szervezik újra az unitárius nyomdát - az unitáriusoknak a 17. század végén már évtizedek óta nincs nyomdájuk, az előd Heltai-nyomda 1661-ben szünik meg. Az új nyomda első kiadványai 1697-ből származnak, s a müködés 1703ig, Kmita Andrásné haláláig folyamatos. A nyomtatványok többségén szerepel, hogy a nyomtatás költségeit Kmita Andrásné fedezte, tudható azonban, hogy az özvegy nyomdászokat alkalmazott. S itt bukkanhatunk rá a kapocsra az unitárius nyomda és Tótfalusi Kis Miklós nyomdája között: az unitárius nyomda vezetöje 1702-ben Heltzdörffer Mihály volt. Heltzdörffer neve fel is tünik a fentebb már nyomdászati példaként szolgáló Florus-kiadás címlapján (a következő oldali kép).

Heltzdörffer Mihályról tudható, hogy korábban Tótfalusi mellett dolgozott nyomdászlegényként, kolozsvári tartózkodását követően pedig Brassóban és Szebenben vezetett városi nyomdát. ${ }^{53}$ Tótfalusi halotti kártájára is szerzett

${ }^{51}$ Haiman György, Tótfalusi Kis Miklós, A betümüvész és a tipográfus, Élete müve betüinek és nyomtatványainak tükrében = Magyar Helikon, 1972, 99.

${ }^{52}$ Például: Perger Péter, A kolozsvári unitárius egyház nyomdájáról való számvetés $=$ Fata libelli, A nyolcvanéves Borsa Gedeon köszöntésére írták barátai és tanítványai, Bp., OSZK, 2013, 289-304; Perger Péter, A kolozsvári unitárius nyomda = A régi magyarországi nyomdák betüi és díszei XVII. század 2. kötet, Kelet-Magyarországi és erdélyi nyomdák, Löcse, Kassa, Tanulmányok és katalógus, Bánfi Szilvia, Pavercsik Ilona, Perger Péter, V. Ecsedy Judit szerk., Balassi Kiadó, Országos Széchényi Könyvtár, Bp., 2014, 132-138; V. Ecsedy Judit, A könyvnyomtatás Magyarországon a kézisajtó korában 1473-1800, Budapest, Balassi, 1999.

53 V. Ecsedy Judit, A könyvnyomtatás Magyarországon a kézisajtó korában 1473-1800, Budapest, Balassi, 1999, 166. 
gyászverset; a kártán neve mellett az, artis typographiae cultor" megnevezés szerepel. Herepei feltételezése szerint Heltzdörffer korábban volt Tótfalusi nyomdászlegénye, nem közvetlenül a Tótfalusi halála körüli időkben. ${ }^{54}$ (Herepei 1702-ből négy nevet tart számon Tótfalusi nyomdászlegényeként: Fekete Jakabét, Németi Mihályét, Telegdi Pap Sámuelét és Miskolczi Csulyak Ferencét. ${ }^{55}$ )

Feltételezésünk szerint tehát az unitárius nyomdából 1702-ben kikerülő $M u$ rányi Vénus Heltzdörffer Mihály kiadványa lehet. Nem tudhatjuk ugyan, hogy az ugyanazon halotti kártákra gyászverset szerzők között milyen szoros lehetett az ismeretség, vagyis hogy a Gyöngyösi-dicsőitő Tétsi Zakariás milyen viszonyban állhatott Heltzdörfferrel, az 1702-es Murányi Vénust a fentiek alapján azonban valamilyen módon kettejük közös vállalkozásának gondoljuk - két református háttérrel rendelkező személy szövetkezésének egy unitárius nyomdában.

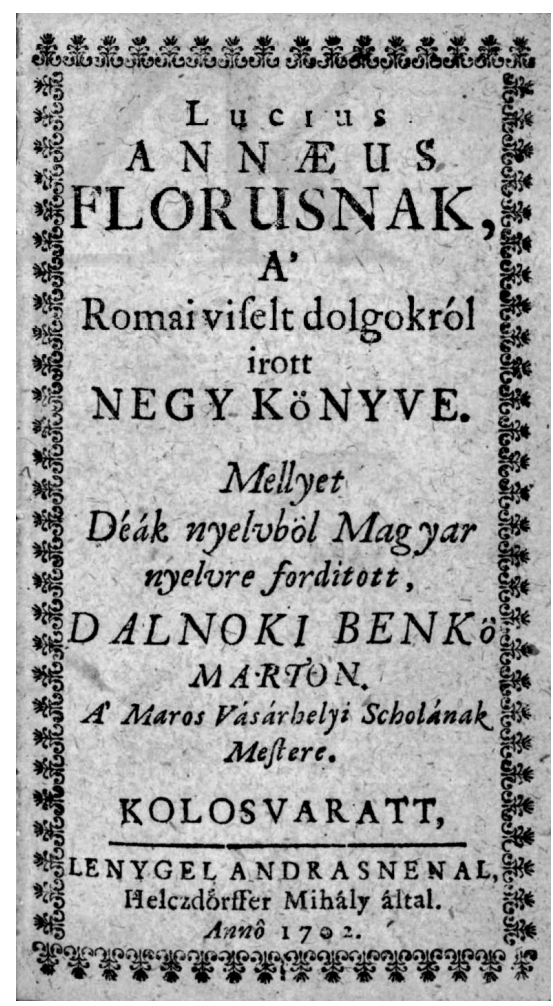

PÁLFY, ESZTER

\section{István Gyöngyösi and Zakariás N. Tétsi - on the 1702 edition of Márssal társolkodó Murányi Vénus}

The present study examines the publication and reception history of István Gyöngyösi's Márssal társolkodó Murányi Vénus (The Venus of Murány in alliance with Mars)

After the first publication in 1664 the book was reprinted in Kolozsvár in 1702 with considerable revision which was not made by its author. All the publications in the eighteenth and the nineteenth centuries were based on this edition. The first time the original Gyöngyösi text was published after the first edition was the one which came out in the twentieth century edited by Ferenc Badics.

From the end of the eighteenth century on, the generally accepted view concerning the 1702 edition of Gyöngyösi's Murányi Vénus has been that the text was faked by the editor. However, it is important to distinguish between editorial practices at the beginning of the eighteenth century and

${ }^{54}$ Herepei, Adattár... III. 1971, i. m. 176.

55 Herepei János, Tótfalusi Kis Miklós kolozsvári mühelye és munkatársai = Magyar Könyvszemle, 1958, 56-62. 
in later periods. Editorial practice at the beginning of the eighteenth century allowed the publisher to freely modify or complete the text while the more autonomous concept of literature prevalent from the end of the eighteenth century provided a more central role to the author. It is only from this latter perspective that the 1702 edition can be considered as a fake and its editor as the one to blame for it.

Recent literature on Gyöngyösi has named Zakariás T(s)étsi as the publisher of the Kolozsvár edition of 1702 but no other information on him has been provided. This name refers to Zakariás Tétsi N., a student of the Reformed Church in Kolozsvár, known for his occasional poetry in Hungarian and Latin at the turn of the seventeenth and eighteenth centuries.

When studying the 1702 edition, one should also state that it was the publication of the Unitarian Officina operating in Kolozsvár between 1697 and 1703.

Keywords: 17-18. centuries, history of civilisation, István Gyöngyösi, Murányi Vénus, Zakariás Tétsi, typography, Cluj-Napoca, reception history 